De Munari, A. ; Schäfer, A.I. ; (2010) Impact of speciation on removal of manganese and organic matter using nanofiltration,

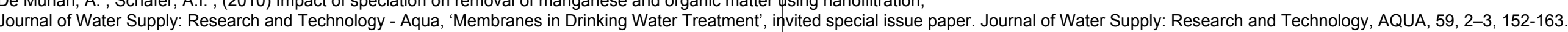
doi: 10.2166/aqua.2010.067

\section{Impact of speciation on removal of manganese and organic matter by nanofiltration}

Annalisa De Munari ${ }^{2 *}$ and Andrea I. Schäfer ${ }^{l}$

${ }^{1}$ School of Engineering, University of Edinburgh, Edinburgh, EH9 3JL, UK Phone: +44 (0) 131650 7860; Fax: +44 (0) 131650 6781;

Email: A.De-Munari@ed.ac.uk

Submitted to

Journal of Water Supply: Research and Technology - AQUA 2010

\section{Abstract}

The removal of manganese and humic acid (HA) by two nanofiltration membranes, TFC-SR2 and TFC-SR3, was investigated in order to highlight the influence of speciation on manganese and HA retention. Manganese speciation and complexation with HA were modelled to understand how speciation could affect NF removal mechanisms. The behaviour of the two membranes was drastically different for manganese retention. Manganese retention for TFC-SR3 was higher and dominated by size exclusion. Manganese retention for TFC-SR2 varied with $\mathrm{pH}$. At $\mathrm{pH} 7$, i.e. the $\mathrm{pH}$ of most natural waters, manganese retention for TFC-SR2 was about $45 \%$ versus $90 \%$ of TFC-

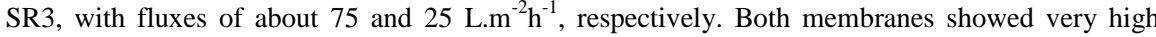
retention of HA (about $80 \%$ ), being therefore suitable for surface waters where no salt removal is required Manganese deposit on both membranes was generally low $(<10 \%)$, but incease 10 and 12 as manganese deposited as precipitated $\mathrm{MnCO}_{3}$, and the membranes showed a yellowbrownish layer.

\section{Keywords}

humic acids, manganese, nanofiltration, speciation

\section{Introduction}

Manganese is one of the most abundant elements on Earth and it occurs in surface water and groundwater naturally and as a result of human activities. Manganese is considered harmful to public health at concentrations higher than $0.4 \mathrm{mg} / \mathrm{L}$. Concentration of manganese exceeding 0.1 $\mathrm{mg} / \mathrm{L}$ creates aesthetic problems of undesirable metallic taste and coloured water at the consumer tap and several countries have set their regulatory limits to $0.05 \mathrm{mg} / \mathrm{L}$ (WHO 2004).

In Scotland, surface waters constitute the majority of the water supply and often contain high concentration of natural organic matter (NOM), as well as iron and manganese (Grose et al. 1998). Water quality data collected by Scottish Water during 2004, 2005 and 2006 at 524 raw water Water quity sample points Scottish-wide showed that iron and manganese exceeded the Scottish maximum
permissible values $(0.05 \mathrm{mg} / \mathrm{L})$ more frequently than aluminium, arsenic, fluoride, lead and nitrite. In particular, manganese was detected at concentrations up to $20 \mathrm{mg} / \mathrm{L}$ (Allen 2008).

Manganese is known to form complexes with humic acids (HA) and tannic acids (TA) (Chiswell \& Mokhtar 1987; Guy \& Chakrabarti 1976; Lee 1983; Nifant'eva et al. 1999). HA represent the largest portion of NOM. NOM is precursor of disinfection by-products, such as trihalomethanes, which are considered carcinogenic (Jacangelo et al. 1995). HA are complex and heterogeneous mixtures of high to low molecular species containing both aromatic and aliphatic components with primarily carboxylic and phenolic functional groups. Most HA groups dissociate at $\mathrm{pH}>4$ and have a negative charge and are insoluble at $\mathrm{pH}<2$ (Hayes et al. 1989).

Removal of manganese together with organic matter is therefore of primary importance in order to comply with regulations and insure that problems of coloured water do not occur. Manganese conventionally removed by filtations process. Oxidation of manganese to precipitated $\mathrm{MnO}_{2}$ is an autocatalytic process and requires strong oxidants (ozone, chlorine or potassium permanganate) and a catalyser (manganese ore or filter sand that has to be pre-treated with manganese). The process is difficult to start-up, the filterability of $\mathrm{MnO}_{2}$ is low and when manganese concentration is higher than $5 \mathrm{mg} / \mathrm{L}$ too much solid is produced that shortens filtration cycles and makes the process unprofitable. Furthermore, process control is difficult for waters of variable quality, such as surface waters (Ellis et al. 2000) The traditional clarification process has proven to be insufficient for manganese removal; moreover, the presence of dissolved organic matter increases the coagulant demand and further decreases the removal (Mijatovic et al. 2004; Potgieter et al. 2005a). In Scotland, manganese exceeded its regulatory limit more frequently than the other inorganic elements (included iron) in sample points at the outlet of conventional water treatment plants, indicating insufficient removal to achieve the desired standard (Allen 2008).

Removal of manganese alone or with organic matter by microfiltration (MF) and ultrafiltration (UF) processes has been investigated in several studies, as summarized in Table 1. Soluble manganese passes through MF and UF membranes and pre-treatments that precipitate manganese are necessary to achieve effective removal. Strong oxidation has been shown to be the most effective pretreatment but this increases the cost of the process, both in economical and environmental terms.

[Table 1]

Nanofiltration (NF) membranes have been applied in the last decades for the removal of specific inorganic compounds (such as arsenic, uranium, and iron) and organic matter (Van der Bruggen \& Vandecasteele 2003). However, only a limited number of studies have examined removal of manganese by NF membranes (Lastra et al. 2004; Molinari et al. 2001; Potgieter et al. 2005b). Lastra et al. (2004) studied manganese and organic removal in the effluent of a pulp mill, characterized by organic content and temperature much higher than the ones found in natural characterized by equence, available results can (2001) performed manganese removal tests with "tap water", but information on water an membrane characteristics was not provided. Potgieter et al. (2005b) used NF membranes for removal of iron and manganese in presence of dissolved organic matter in a South African river Manganese concentrations in the river water were very low $(0.15-0.29 \mathrm{mg} / \mathrm{L})$, probably similar to the instrument detection limit, increasing the detection error in the membrane permeate. Differen samples with different solute concentrations were used, making results not comparable in a consistent way. The Fyne process using NF PCI membranes has been reported to work satisfactorily for the removal of organic matter, manganese and iron in North America and Scotland (Grose et al. 1998; Pearon 2001; Wittmann \& Thorsen 2004). However, the obtained removal sates were site and condition dependent and they can not be generalized. This invites to a systematic approach to elucidate underlying mechanisms applicable to water treatment.

The results obtained in the reviewed studies are dependent on the feed water characteristics and on the particular conditions in which the experiments were carried on and they can not be easily compared. In these studies NF was shown to be a suitable process for manganese removal, however its removal mechanisms were not consistently investigated and membrane characteristics (morphology and charge) affecting retention were not taken into account. Furthermore, the impact 
De Munari, A. ; Schäfer, A.I. ; (2010) Impact of speciation on removal of manganese and organic matter using nanofiltration,

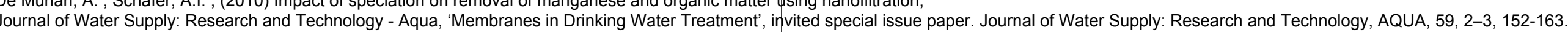
doi: 10.2166/aqua.2010.067

of manganese speciation and complexation with organic matter was not taken into consideration. Although NF is known to remove divalent co-ions, removal is solute specific due to solut speciation and different interaction with the membranes. Relating solute removal and flux to solution $\mathrm{pH}$ has been shown to be mandatory for understanding removal mechanisms by $\mathrm{NF}$ membranes, as the variation of solution $\mathrm{pH}$ affects not only membrane characteristics but also the different forms (species) at which solutes exist (Childress \& Elimelech 2000). Despite this, the removal mechanisms is limited.

In consequence, the objectives of this study were to:

(1) Model manganese speciation in presence of HA

(2) Investigate and quantify the influence of $\mathrm{pH}$ and speciation on removal of manganese and $\mathrm{HA}$ by NF

(3) Explain the mechanism of manganese and HA removal by two NF membranes

In order to study manganese and HA removal, TFC-SR2 and TFC-SR3S NF membranes were selected and experiments were carried out at $\mathrm{pH}$ ranging from 4 to 12 . TFC-SR2 and TFC-SR3 selected and experiments were carried out at $\mathrm{pH}$ ranging from 4 to 12 . TFC-SR2 and TFC-SR3
present attractive characteristics for manganese and HA removal, since they have high organics present attractive characteristics for manganese and HA removal, since they have high organics
retention and partial retention of inorganics. Speciation of manganese and complexation of manganese and HA were modelled to interpret retention results.

\section{Materials and Methods}

\section{Chemicals}

Experiments were conducted in ultra-pure water obtained by PuraLab Ultra (Elga LabWater, UK). All chemicals were of analytical grade. Manganese as $\mathrm{MnCl}_{2}$ was purchased from Fisher Scientific UK and HA from Sigma Aldrich UK. Characteristics of Aldrich HA can be found in the literature (Kim et al. 1990; Malcom \& MacCarthy 1986). Manganese was used at a concentration of $5 \mathrm{mg} / \mathrm{L}$ and $\mathrm{HA}$ of $5 \mathrm{mgC} / \mathrm{L}$, as these are representative concentrations for Scottish waters (Allen 2008) Electrolyte background solution consisted of $1 \mathrm{mM} \mathrm{NaHCO}_{3}$ and $20 \mathrm{mM} \mathrm{NaCl}$, both supplied by Fisher Scientific. pH was adjusted with1M $\mathrm{HCl}$ and $\mathrm{NaOH}$ (Fisher Scientific, UK). Nitric acid for sample conservation was purchased by Aristar VWR International, UK.

\section{Stirred cell filtration system}

Experiments were performed with an apparatus consisting of three stainless steel stirred cells in parallel described elsewhere (Neale 2009) and depicted in Figure 1. Cells had volume of $990 \mathrm{~mL}$ and a diameter of $70 \mathrm{~mm}$, resulting in a membrane area of $38.5 \mathrm{~cm}^{2}$. The cells were pressurised with filtered lab air; the pressure was kept constant and automatically measured every minute with a pressure transducer (Omega Engineering, UK). Temperature inside the cells and permeate collected magnetic stirrer (Fisher Scientific, UK) was used at speed of $300 \mathrm{rpm}$.

[Figure 1]

\section{Membranes}

Two proprietary thin-film composite (TFC) membranes made by a thin layer of polyamide cast on a layer of microporous polysulfone, TFC-SR2 and TFC-SR3, supplied by Koch Membrane, UK, were selected for this study (Koch Membrane System Fluid System Datasheets). All experiments were performed with one batch flat sheet membrane sample provided by the manufacturer and a new membrane was used for each experiment. Membrane characteristics are summarized in Table 2. Permeability was calculated as the average of all measurements performed in this study. Pore radius and molecular weight cut-off (MWCO) were determined using the methodology described by Nghiem et al. (2004).

The membrane contact angle has been measured using the sessile drop method with a contact angle measuring instrument (Easy Drop, Kruss, Germany). Point of zero charge was measured with an electrokinetic analyser (EKA, Anton Paar KG, Graz, Austria) with the same background electrolyte used in the experiments $\left(1 \mathrm{mM} \mathrm{N} \mathrm{HCO}_{3}\right.$ a $20 \mathrm{mM} \mathrm{NCl}$ ). TFC-SR2 and TFC-SR3 membres used in the experiments are amphoteric, i.e. they have ionizable cart is positive at $\mathrm{pH}$ lower than the point of zero charge due to the protonation of amine groups $\left(\equiv \mathrm{NH}_{2} \rightarrow \equiv \mathrm{NH}_{3}{ }^{+}\right)$and negative at higher $\mathrm{pH}$, due to the deprotonation of carboxylic groups $\left(\equiv \mathrm{COOH} \rightarrow \equiv \mathrm{COO}^{-}\right)$(Childress \& Elimelech 1996). The two membranes showed similar surface charge characteristics, with similar point of zero charge (at pH 4.25 for TFC-SR2 and $\mathrm{pH} 3.84$ for TFC-SR3) and similar zeta potential at $\mathrm{pH} 12(-26.7 \pm 9.2$ for TFC-SR2 and $-26.8 \pm 5.5$ for TFCSR3), while TFC-SR2 was slightly more positively charged at $\mathrm{pH} 3.5(2.2 \pm 4.7$ for TFC-SR2 and $1.2 \pm 5.7$ for TFC-SR3).

[Table 2]

\section{Experimental Protocol}

The experiment protocol was as follows: the membrane was thoroughly rinsed with ultra-pure water, stored in ultra-pure water overnight and compacted for an hour at 8 bar. Pure water flux was measured at 5 bar for 30 minutes before each experiment. $500 \mathrm{~mL}$ feed solution, prepared the day before and stirred overnight at $100 \mathrm{rpm}$, was placed in the cell and pressurized at 5 bar. Permete was collected in three aliquots of $40 \mathrm{~mL}$ each ( $24 \%$ recovery). Pure water flux was measured at 5 bar for 30 minutes after the experiment.

Three types of experiment were conducted:

1. $\mathrm{Mn}^{2+}$ only: feed solution contained $5 \mathrm{mg} / \mathrm{L}$ of $\mathrm{Mn}^{2+}$ and background electrolyte. A stock solution of $100 \mathrm{mg} / \mathrm{L}$ of $\mathrm{Mn}^{2+}$ was acidified and stored at $<4^{\circ} \mathrm{C}$.

2. HA only: feed solution contained $5 \mathrm{mgC} / \mathrm{L}$ of $\mathrm{HA}$ and background electrolyte. A stock solution of $100 \mathrm{mgC} / \mathrm{L}$ of $\mathrm{HA}$ was wrapped in aluminium foil and stored at $<4{ }^{\circ} \mathrm{C}$ for not more than 2 weeks.

3. $\mathrm{Mn}^{2+}$ and HA: feed solutions contained $5 \mathrm{mg} / \mathrm{L}$ of $\mathrm{Mn}^{2+}, 5 \mathrm{mgC} / \mathrm{L}$ of $\mathrm{HA}$ and background electrolyte.

Error bars were determined by considering pure water flux variation due to the use of different membrane samples, variation in temperature and pressure during different experiments and within the same experiment and error in determining solute concentration due to error in pipette, in balance, volumetric flask and instrumental error. Pure water flux variations were found to be $4.3 \%$ for TFC-SR2 and $8.5 \%$ for TFC-SR3, the instrumental error for ICP-OES (inductively coupled plasma atomic emission spectroscopy) was $3.6 \%$ and for total organic carbon (TOC) was $5.8 \%$, (the was considered instead.

\section{Analytical Methods}

Samples and blanks were analysed for manganese with ICP-OES (Perking Elmer Optima 5300 DV, UK) after being acidified with nitric acid to $\mathrm{pH}<2$ for conservation (Clesceri et al. 1998). Calibration standards were made using ICP multi-element standard and manganese standard (Merck, Germany) and verified using a certified reference material, ICP multi-element standard solutions VI (CertiPUR, Germany). Total Organic Carbon (TOC) was measured with a TOC $\mathrm{V}_{\mathrm{CPH} / \mathrm{CPN}}$ Shimadzu analyser in a non-purgeable organic carbon mode. Calibration standards were 
De Munari, A. ; Schäfer, A.I. ; (2010) Impact of speciation on removal of manganese and organic matter using nanofiltration,

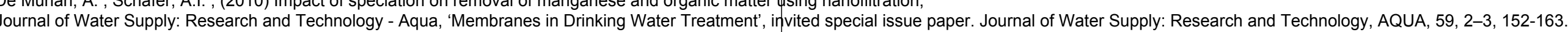
doi: 10.2166/aqua.2010.067

made using potassium hydrogen phthalate (Acros Organics, UK). Samples were analysed for TOC the same day of the experiments. Ultraviolet absorbance at $254 \mathrm{~nm}$ was measured with an UV Visible Spectrophometer Cary 100 (Varian, UK). Samples were analyzed within a few hours from collection. Conductivity and $\mathrm{pH}$ measurements were conducted using a $\mathrm{pH} /$ Cond $340 \mathrm{i}$ meter (WTW, Germany).

\section{Speciation Modelling}

Visual MINTEQ 2.5 (U.S. Environmental Protection Agency 1991) was used in this study to mode both manganese speciation and manganese and $\mathrm{HA}$ complexation as a function of $\mathrm{pH}$. Modelling was carried out for the experimental conditions $\mathrm{Mn}^{2+}$ fixed at $5 \mathrm{mg} / \mathrm{L}, 20 \mathrm{mM}$ of background electrolyte, $\mathrm{pH}$ from 4 to 12 and pressure fixed at 5 bar. It was assumed that no redox reaction for Mn(II) occurred during the experiments, despite the presence in the stirred cells of dissolved oxygen at concentrations higher than in a solution in equilibrium with the atmosphere. The oxidation reaction of $\mathrm{Mn}$ (II) into Mn(IV) is very slow (days) in absence of catalytic effects and aeration alone has $\mathrm{MnO}_{2}$, the dominan (II) was considered the only oxidation state for manganese during the experiments.

The NICA-Donnan Model present in Visual MINTEQ 2.5 (U.S. Environmental Protection Agency 1991) was chosen as it has been extensively validated over experimental data for several elements, such as $\mathrm{H}^{+}, \mathrm{Ca}^{2+}, \mathrm{Cd}^{2+}, \mathrm{Cu}^{2+}, \mathrm{Pb}^{2+}, \mathrm{Al}^{2+}$ (Benedetti et al. 1995; Christl et al. 1995; Kinniburgh et al. 1999; Pinheiro et al. 2000) and $\mathrm{Fe}^{3+}$ (Weber et al. 2006a; Weber et al. 2006b). Detailed description of the NICA-Donnan model can be found in the literature (Kinniburgh et al. 1999; Merdy et al. 2006). NICA sub-model simulases specific metal-NOM binding and uses two binding functions corresponding to the carboxylic and phenolic groups of HA. A continuous distribution of binding sites types is assumed. Donnan sub-model simulates non-specific binding due to the electrostatic forces caused by the net negative charge of dissociated carboxylic and phenolic groups. The organic matter is considered as a gel phase with homogenous charge and potential distribution and counterions are assumed to accumulate in the gel volume. The two sub-models are interrelates, as the concentration of ions accumulated electrostatically competes with the ions bind specifically, and they were used simultaneously. As specific experimental data with manganese ions were not available in the literature, NICA-Donnan model parameters derived by Milne et al. (2003) were

indication of the likely binding capacity of humic substance (Milne et al. 2003).

\section{Results and Discussions}

\section{Manganese and HA speciation}

The distribution of manganese species alone or in presence of HA was modelled as a function of $\mathrm{pH}$. Modelling the complexation of metals wi heterogeneous and complex nature of humic binding sites, the presence of electostic interactions and the competing binding of protons as they interact with the same sites as metals ions (Merdy $e t$ al. 2006).

Figure 2 (A) and (B) show the percentage of manganese in solution and manganese precipitate in absence and presence of HA. Figure 2 (C) details the concentration of dissolved manganese, expressed as logarithmic of the activity, versus $\mathrm{pH}$ in absence of HA. Dissolved manganese species in presence of HA showed the same trends, albeit with slightly different concentrations (results not reported).

[Figure 2]
At $\mathrm{pH}<7$, dissolved manganese is mainly present as $\mathrm{Mn}^{2+}, \mathrm{MnHCO}_{3}{ }^{+}, \mathrm{MnOH}^{+}$and $\mathrm{MnCO}_{3}$ (aq). $\mathrm{MnCO}_{3}$ precipitation starts at $\mathrm{pH} 7.1$ (dashed line in Figure 2(C)) and it is complete at $\mathrm{pH} 9.6$ Figure 2(A) and (C) are in agreement with published investigations on the chemistry of manganese in natural waters (Chiswell \& Mokhtar 1986; Chiswell \& Mokhtar 1987).

In presence of $\mathrm{HA}$, the distribution of dissolved manganese species does not vary greatly and $\mathrm{Mn}^{2+}$, $\mathrm{MnHCO}_{3}{ }^{+}, \mathrm{MnOH}^{+}$and $\mathrm{MnCO}_{3}(\mathrm{aq})$ remain the dominant dissolved manganese species (results not presented). As shown in Figure 2(B), $\mathrm{MnCO}_{3}$ starts precipitating at $\mathrm{pH} 7.2$ and the precipitation is completed at $\mathrm{pH}$ 8.5. The presence of $\mathrm{HA}$ does not influence the $\mathrm{pH}$ at which manganese starts completed at $\mathrm{pH} 8.5$. The presence of $\mathrm{HA}$ does not influence the $\mathrm{pH}$ at which manganese starts
precipitating, but lowers the $\mathrm{pH}$ at which the maximum quantity of precipitate is present from $\mathrm{pH}$ 9.6 to 8.5 . Furthermore, in presence of $\mathrm{HA}$, there is $35 \%$ less precipitation of $\mathrm{MnCO}_{3}$ as the manganese forms complexes with HA.

The obtained speciation graph in presence of HA must be used with caution, given the number of assumptions done and the use of parameters that have not been experimentally validated. However the results are in general agreement with the literature Organic matter was shown to influence the solubility of inorganic compounds (Lee 1983) and in particular to increase metal ion solubility through binding with dissolved organic matter (Kinniburgh et al. 1999; Schäfer 2001; Weber et al. 2006b). The increase of metal-HA complexes with $\mathrm{pH}$ was observed for $\mathrm{Fe}^{3+}$ (Weber et al. 2006b) and $\mathrm{Ca}^{2+}$ (Hong \& Elimelech 1997) and this is due to the availability of carboxyl functional groups of $\mathrm{HA}$ at higher $\mathrm{pH}$ (Hong \& Elimelech 1997)

\section{Membrane flux}

Figure 3 shows the ratio of pure water flux after $(\mathrm{J})$ and before $(\mathrm{Jo})$ the experiments versus $\mathrm{pH}$ Water flux decline after the experiments was not observed, showing that membrane fouling did not occur. Lack of fouling was attributed to the short duration of the experiments, the low concentrations of the solutes and the relatively low flux obtained in the stirred cells. The absence of fouling allowed relating the obtained retention results directly to the membrane characteristics and solute speciation, without considering membrane and solute modification due to the formation of the fouling layer.

[Figure 3]

In some cases, especially for TFC-SR3 water flux after experiments was enhanced, resulting in a flux ratio greater than one. This phenomenon was observed in a study by Hong and Elimelech (1997) and was attributed to the hydrophilization of membrane surface by adsorbed solutes. Adsorption of negative solutes, such as HA, can increase the membrane negative charge, thus its hydrophilicity. However in this study, flux enhancement occurred for TFC-SR3 also when $\mathrm{Mn}^{2+}$ alone was present indicating that ions can enhance permeability also. As shown in Figure 3, TFC$\mathrm{SR} 2$ experienced a slight flux ratio increase at higher $\mathrm{pH}$ due to pore opening with increased charge repulsion, while no trend could be observed for TFC-SR3.

During the experiments the permeability was relatively constant for both membranes (Figure 4), if error fluxes are taken into account $(4.3 \%$ for TFC-SR2 and $8.5 \%$ for TFC-SR3, error bars not shown for clarity). This was also observed by Schäfer (2001) for other TFC membranes. When electrolyte only was used, TFC-SR2 showed a slightly flux increase at $\mathrm{pH} 8$, while maximum flux for TFC-SR3 was obtained at $\mathrm{pH}$ 6. This is in contrast with the Donnan exclusion theory that predicts maximum flux and minimum electrolyte retention at the membrane zero point of charge (at around $\mathrm{pH} 4$ for both membranes, see Table 2 ).

[Figure 4] 
De Munari, A. ; Schäfer, A.I. ; (2010) Impact of speciation on removal of manganese and organic matter using nanofiltration,

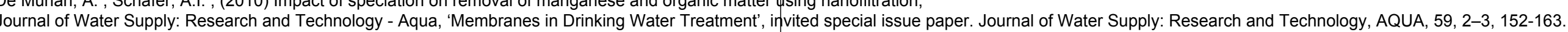
doi: 10.2166/aqua.2010.067

\section{Solute retention and precipitation}

Manganese and HA retention was calculated for HA only, manganese only and when both were present (Figure 5)

[Figure 5]

Manganese retention was higher for TFC-SR3 membrane in agreement with salt retention reported by the manufacturer and $\mathrm{NaCl}$ retention determined in this study (Table 1). Furthermore, manganese retention by TFC-SR3 (Figure 5(B)) did not show high variation with $\mathrm{pH}$ (error in calculating manganese retention 7.8\%) and it was high (94.7\%) at lower $\mathrm{pH}$ when manganese is mainly present as dissolved $\mathrm{Mn}^{2+}$ (Figure 2). Hydrated radius for $\mathrm{Mn}^{2+}$ has been calculated as 0.44 $\mathrm{nm}$ (Nightingale 1959), while the calculated pore radius of TFC-SR3 was $0.38 \mathrm{~nm}$ (Table 2). . When to predict better than crystal and Stokes radius ion passages through metris through membranc Schaep et al. 1998). As a consequence, ions are hindered to enter the pores and size exclusion is the main removal mechanism.

Manganese retention by TFC-SR2 (see Figure 5(A)) was high at $\mathrm{pH} 4(92.2 \%)$ and at $\mathrm{pH} 10-12$ (99.1\%) with a minimum $(37.3 \%$ ) at $\mathrm{pH} 8$. At $\mathrm{pH} 10$ and 12 manganese is predominantly present as visible $\mathrm{MnCO}_{3}(\mathrm{~s})$ that precipitated on the membrane and manganese removal was mainly due to size exclusion. Between $\mathrm{pH} 7$ and 4 almost all manganese is present as soluble $\mathrm{Mn}^{2+}$. High manganese retention at $\mathrm{pH} 4$ can not be explained by steric hindrance, as the hydrated radius of $\mathrm{Mn}^{2+}(0.44 \mathrm{~nm})$ is smaller than the average pore size of TFC-SR2 $(0.52 \mathrm{~nm})$, nor by charge Mn repulsion forces between the membrane surface and the solute, as TFC-SR2 has point of zero charge at $\mathrm{pH} 4.25$ (Table 2). Minimum retention of ions is expected in correspondence of the poin of zero charge of the membrane surface, when the repulsion forces are minimum (Mänttäri et al. 2006). In this study, instead, minimum retention for TFC-SR2 occurred at $\mathrm{pH} 8$, higher that the point of zero charge of the membrane surface.

Childress and Elimelech (2000) observed minimum retention of $\mathrm{NaCl}$ at the point of zero charge of the membrane pores, which they showed to be higher than the point of zero charge of the membrane surface. When pores are charged, the electrostatic repulsion between the membrane functional surface. When pores are charged, the electrostatic repulsion between the membrane functional
groups causes the pore to expand; at their point of zero charge the pore size would not be reduced, groups causes the pore to expand; at their point of zero charge the pore size would not be reduced,
flux would be maximum and salt retention minimum. They inferred that for "loose" porous flux would be maximum and salt retention minimum. They inferred that for "loose" porous membranes pore charge could be more important than surface charge in controlling flux and sal retention. Pore charge becomes important when solutes are not hindered to enter the pores. When friction forces within the pores acquire importance (Pontalier et al. 1997). This mechanism might be confirmed by the experimental results for TFC-SR2 as the flux is maximum at $\mathrm{pH} 8$ (Figure 4 ) increase of retention at $\mathrm{pH} 6$ and 4 , where the pores will be positively charged.

Considering the error of TOC analysis and of retention calculation (6.9\% and $11.4 \%$ respectively), retention of HA was high for both membranes (about $80 \%$ ) and did not present a specific trend with $\mathrm{pH}$. These results were confirmed by retention calculated by analysing samples with ultraviole absorbance at $254 \mathrm{~nm}$ (results not presented). The ratio $\mathrm{UV}_{254 \mathrm{~nm}} / \mathrm{TOC}$ (SUVA) was calculated as an indication of the aromaticity of the samples and SUVA retention was determined as a function of $\mathrm{pH}$. Both membranes showed high aromaticity retention (83-93\% for TFC-SR2 and 80-100\% for TFC-SR3) and no trend with $\mathrm{pH}$ could be observed. The presence of manganese did not affect The retention. Also manganese retention was not affected by the presence of HA, as it is evident by the same trend of the curves for $\mathrm{Mn}^{2+}$ only and for $\mathrm{Mn}^{2+}$ and $\mathrm{HA}$ in Figure 5. Even though several studies documented the formation of complexes between manganese and HA (Chiswell \& Mokhtar 1987; Guy \& Chakrabarti 1976; Lee 1983; Nifant'eva et al. 1999) and the NICA-Donnan model predicted that $37 \%$ of manganese in solution would complex to HA at $\mathrm{pH}$ above 7.2 (Figure 2), a significant enhancement of manganese and HA retention when both elements were present was not observed. In the case of TFC-SR3 membrane, high retention was already achieved due to size In

It can be concluded that at $\mathrm{pH} 7$, i.e. the $\mathrm{pH}$ of most natural waters, the behaviour of the two membranes was drastically different for manganese retention. TFC-SR3 presented retention above $95 \%$, due mainly to size exclusion, while TFC-SR2 presented retention of about $45 \%$. At pH 7 both membranes had high retention of HA (about $80 \%$ ) showing to be particularly suitable for surface waters. To achieve a drinking water quality of $0.05 \mathrm{mg} / \mathrm{L}$ with the feedwater concentration of 5 $\mathrm{mg} / \mathrm{L}$ a retention of $99 \%$ is required. This can only be achieved at $\mathrm{pH} 10$ and 12 for both membranes.

\section{Mass deposit on the membrane}

Mass deposit on the membranes was determined to substantiate the results obtained in the previous section. The deposit of manganese and HA on the membranes was calculated with the following mass balance equation

$$
\mathrm{M}_{\mathrm{D}}=\mathrm{V}_{\mathrm{F}} \mathrm{C}_{\mathrm{F}}-\mathrm{V}_{\mathrm{P}} \mathrm{C}_{\mathrm{P}}-\mathrm{V}_{\mathrm{C}} \mathrm{C}_{\mathrm{C}}(1)
$$

where $\mathrm{M}_{\mathrm{D}}$ is amount of solute the deposit, $\mathrm{V}_{\mathrm{F}} \mathrm{V}_{\mathrm{P}}$ and $\mathrm{V}_{\mathrm{C}}$ are the volume of feed, permeate, and concentrate, respectively, and $C_{F}, C_{P}$ and $C_{c}$ are the concentration of feed, permeate and concentrate, respectively.

[Figure 6]

As shown in Figure 6, the deposit of solutes was low, generally less than $10 \%$. However, when $\mathrm{Mn}^{2+}$ only was present in solution, manganese deposit was higher for $\mathrm{pH} 10$ and 12 , as manganese deposited as precipitated $\mathrm{MnCO}_{3}$, and the membranes showed a yellow-brownish layer (Figure 6 (A) and (B)). For both membranes, manganese deposit at high $\mathrm{pH}$ was generally less when $\mathrm{HA}$ were present. Considering the high error associated with HA mass deposit calculation (10.0\%), HA deposit with and without manganse can be considered negigible for both meranes This result agreed with mass deposit calculations obtained using UV absorbance data (results not presented) and visual observations, confirming that fouling did not occur during the experiments.

The short duration of the experiments and the low concentration of the solutes did not allow to obtain fouling conditions. However, in longer filtration operation the presence of HA and manganese precipitation at high $\mathrm{pH}$ is likely to decrease membrane flux and reduce membrane performance including decrease of solute retention. Further studies are required to investigate this phenomenon.

\section{Conclusions}

This study investigated the removal of manganese and HA by two NF membranes, TFC-SR2 and TFC-SR3, as a function of $\mathrm{pH}$

- The two membranes showed different behaviour respect to manganese retention

- Both membranes had high retention of HA (about 80\%)

- Solute deposit on both membranes was speciation dependent. 
De Munari, A. ; Schäfer, A.I. ; (2010) Impact of speciation on removal of manganese and organic matter using nanofiltration,

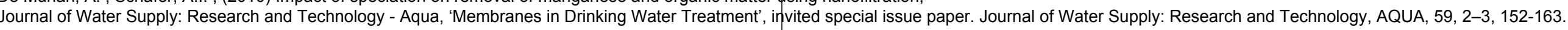
doi: 10.2166/aqua.2010.067

TFC-SR3 had higher manganese retention (about 96\%) for all the investigated $\mathrm{pH}$ and this was attributed to size exclusion. Manganese retention for TFC-SR2 varied with $\mathrm{pH}$ : higher retention was obtained at $\mathrm{pH} 10$ and 12, due to manganese precipitation as insoluble $\mathrm{MnCO}_{3}$, and at $\mathrm{pH} 4$, while lower retention was observed at $\mathrm{pH} 6$ and 8. At $\mathrm{pH} 7$, i.e. the $\mathrm{pH}$ of most natural waters, manganese retention for TFC-SR2 was about $45 \%$, versus $90 \%$ for TFC-SR3. For both membranes, the manganese regulatory limit in the permeate $(0.05 \mathrm{mg} / \mathrm{L})$ was only reached at $\mathrm{pH} 10$ and $12(99 \%$ retention). Both membranes showed to be particularly suitable for surface waters where NOM is (1) present. On boh $(<10 \%)$, but increased at $\mathrm{pH} 10$ and 12 as manganese deposited as precipitated $\mathrm{MnCO}_{3}$, and the membranes showed a yellow-brownish layer.

The complexation model showed formation of manganese-HA complexes at $\mathrm{pH}$ values above 7 However, significant enhancement of manganese and HA retention when both elements were present was not observed during the experiments, as manganese retention was not affected by the presence of $\mathrm{HA}$ and vice versa $\mathrm{HA}$ retention was not affected by the presence of manganese. In the case of TFC-SR3 membrane, high retention was already achieved due to size exclusion mechanisms, while for TFC-SR2, precipitation might overlap with complexation effects.

\section{Acknowledgments}

The authors would like to thank Koch Membranes for kindly providing the membranes used during the experiments, Dr. Alexander Bismarck and Dr. Kingsley Ho for assistance with zeta potential and contact angle measurements, Helfrid Rossiter for assistance with the ICP-OES analysis, Laur (Scottish Water) for providing data and information on Scottish membrane plants. Thanks are also extended to the Drinking Water Quality Regulator for Scotland and the School of Engineering of The University of Edinburgh for funding the PhD studentship for De Munari.

\section{References}

Abdur Rahman, M., Huang, J. Y., Iwakami, Y. \& Fujita, K. (2000) Pursuing the effect of aeration $\mathrm{pH}$ increment, and $\mathrm{H}_{2} \mathrm{O}_{2}$ coupled with UV irradiation on the removal efficiency of manganese by microfilter membrane, Water Science and Technology 41(10-11), 25-31.

Allen, R. (2008) Analytical data supplied courtesy of Scottish Water (2004-2006).

Benedetti, M. F., Milne, C. J., Kinniburgh, D. G., Van Riemsdijk, W. H. \& Koopal, L. K. (1995) Metal ion binding to humic substances: application of the non-ideal competitive adsorption model, Environ. Sci. Technol 29 (2), 446-457.

Childress, A. E. \& Elimelech, M. (1996) Effect of solution chemistry on the surface charge of polymeric reverse osmosis and nanofiltration membranes, Journal of Membrane Science 119(2), 253-268.

Childress, A. E. \& Elimelech, M. (2000) Relating nanofiltration membrane performance to membrane charge (electrokinetic) characteristics, Environ. Sci. Technol 34(17), 3710-3716.

Chiswell, B. \& Mokhtar, M. B. (1986) The speciation of manganese in freshwaters, Talanta 33(8), 669-677.

Chiswell, B. \& Mokhtar, M. B. (1987) Speciation of manganese in fresh water--I : Use of EPR studies, Talanta 34(3), 307-311.

Choo, K.-H., Lee, H. \& Choi, S.-J. (2005) Iron and manganese removal and membrane fouling during UF in conjunction with prechlorination for drinking water treatment, Journal of Membrane Science 267(1-2), 18-26.

Christl, I., Milne, C. J., Kinniburgh, D. G. \& Kretzschmar, R. (1995) Relating ion binding by Fulvic and Humic Acids to chemical composition and molecular size. 2. metal binding, Environ. Sci. Technol 29(2), 2512-2517.

Clesceri, L. S., Greenberg, A. E. \& Eaton, A. D. (1998) Standard methods for the examination of water and wastewater - 20th Edition.

Ellis, D., Bouchard, C. \& Lantagne, G. (2000) Removal of iron and manganese from groundwater by oxidation and microfiltration, Desalination 130(3), 255-264.

Grose, A. B. F., Smith, A. J., Donn, A., O'Donnell, J. \& Welch, D. (1998) Supplying high quality drinking water to remote communities in Scotland, Desalination 117(1-3), 107-117.

Guy, R. D. \& Chakrabarti, C. L. (1976) Studies of metal-organic interactions in model systems pertaining to natural waters, Canadian Journal Chemistry 54(1), 2600-2611.

Han, S.-C., Choo, K.-H., Choi, S.-J. \& Benjamin, M. M. (2007) Modeling manganese removal in chelating polymer-assisted membrane separation systems for water treatment, Journal of Membrane Science 290(1-2), 55-61.

Handa, B. K. (1970) Chemistry of manganese in natural waters, Chemical Geology 5(161-165.

Hayes, M. H. B., MacCarthy, P., Malcom, R. L. \& Swift, R. S. (1989) The search for structure: setting the scene in Humic Substance II John Wiley \& Sons, New York. 
De Munari, A. ; Schäfer, A.I. ; (2010) Impact of speciation on removal of manganese and organic matter using nanofiltration,

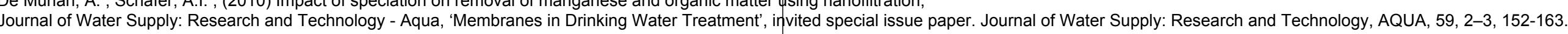
doi: 10.2166/aqua.2010.067

Hong, S. \& Elimelech, M. (1997) Chemical and physical aspects of natural organic matter (NOM) fouling of nanofiltration membranes, Journal of Membrane Science 132(2), 159-181.

Jacangelo, J. G., DeMarco, J., Owen, D. M. \& Randtke, S. J. (1995) Selected processes for removing NOM: an overview, Journal AWWA Jan 95(64-77.

Jimbo, Y. \& Goto, K. (2001) Iron and manganese removal by a membrane filtration system, Water Science and Technology: Water Supply 1(5/6), 357-364.

Kabsch-Korbutowicz, M. \& Winnicki, T. (1996) Application of modified polysulfone membranes to the treatment of water solutions containing humic substances and metal ions, Desalination 105(12), 41-49.

Kim, J. I., Buckau, G., Dushner, H. \& Psarros, N. (1990) Characterization of humic and fulvic acids from Gorleben groundwater, Fresenius' Journal of Analytical Chemistry 338(1), 245-252.

Kinniburgh, D. G., van Riemsdijk, W. H., Koopal, L. K., Borkovec, M., Benedetti, M. F. \& Avena, M. J. (1999) Ion binding to natural organic matter: competition, heterogeneity, stoichiometry and thermodynamic consistency, Colloids and Surfaces A: Physicochemical and Engineering Aspects 151(1-2), 147-166.

Koch Membrane System Fluid System Datasheets.

http://www.kochmembrane.com/support_nf_lit.html last accessed on January 2009.

Lastra, A., Gómez, D., Romero, J., Francisco, J. L., Luque, S. \& Álvarez, J. R. (2004) Removal of metal complexes by nanofiltration in a TCF pulp mill: technical and economic feasibility, Journal of Membrane Science 242(1-2), 97-105.

Lee, J. (1983) Complexation analysis of fresh waters by equilibrium diafiltration, Water Research 17(5), 501-510.

Malcom, R. L. \& MacCarthy, P. (1986) Limitation in the use of commercial humic acids in water and soil research, Environ. Sci. Technol 20(9), 904-911.

Mänttäri, M., Pihlajamäki, A. \& Nyström, M. (2006) Effect of pH on hydrophilicity and charge and their effect on the filtration efficiency of NF membranes at different $\mathrm{pH}$, Journal of Membrane Science 280(1-2), 311-320.

Merdy, P., Huclier, S. \& Koopal, L. K. (2006) Modeling metal-particle interactions with an emphasis on natural organic matter, Environ. Sci. Technol 40(24), 7459-7466.

Mijatovic, I., Matosic, M., Hajduk Cerneha, B. \& Bratulic, D. (2004) Removal of natural organic matter by ultrafiltration and nanofiltration for drinking water production, Desalination 169(3), 223matter by
230.

Milne, C. J., Kinniburgh, D. G., Van Riemsdijk, W. H. \& Tipping, E. (2003) Generic

NICA-Donnan model parameters for metal-ion binding by humic substances, Environ. Sci. Technol 37(5), 958-971.

Molinari, R., Argurio, P. \& Romeo, L. (2001) Studies on interactions between membranes (RO and $\mathrm{NF})$ and pollutants $\left(\mathrm{SiO}_{2}, \mathrm{NO}^{3-}, \mathrm{Mn}^{++}\right.$and humic acid) in water, Desalination 138(1-3), 271-281.

Neale, P. (2009) The Influence of solutes-solutes interactions in membrane filtration, PhD Thesis, The University of Edinburgh.
Nghiem, L. D., Schäfer A. I. \& Elimelech, M. 2004 Removal of natural hormones by nanofiltration membranes: measurement, modeling and mechanisms. Environ. Sci. Technol. 38(6), 1888-1896.

Nifant'eva, T. I., Shkinev, V. M., Spivakov, B. Y. \& Burba, P. (1999) Membrane filtration studies of aquatic humic substances and their metal species: a concise overview. Part 2. Evaluation of conditional stability constants by using ultrafiltration, Talanta 48(2), 257-267.

Nightingale, E. R. (1959) Phenomenological theory of ion solvation. Effective radii of hydrated ions, J. Phys. Chem. 63(9), 1381-1387.

Pearson, D. (2001) Surface-water systems use membranes to remove disinfection by-product precursors, Membrane Technology 2001(134), 4-7.

Pinheiro, J. P., Mota, A. M. \& Benedetti, M. F. (2000) Effect of aluminum competition on lead and cadmium binding to humic acids at variable ionic strength, Environ. Sci. Technol 34(24), 51375143.

Pontalier, P.-Y., Ismail, A. \& Ghoul, M. (1997) Mechanisms for the selective rejection of solutes in nanofiltration membranes, Separation and Purification Technology 12(2), 175-181.

Potgieter, J. H., Potgieter-Vermaak, S. S., Modise, J. \& Basson, N. (2005a) Removal of iron and manganese from water with a high organic carbon loading. Part II: The effect of adsorbent and nanofiltration membranes, Water, Air, and Soil Pollution 162(1), 61-70.

Potgieter, J. H., Mccrindle, R. I., Sihlali, Z., Schwarzer, R. \& Basson, N. (2005b) Removal of iron and manganese from water with a high organic carbon loading. Part I: The effect of various coagulants Water, Air, and Soil Pollution 162(1), 29-59.

Schaep, J., Van der Bruggen, B., Vandecasteele, C. \& Wilms, D. (1998) Influence of ion size and charge in nanofiltration, Separation and Purification Technology 14(1-3), 155-162.

Schäfer, A. I. (2001) Natural organics removal using membranes: principles, performance and cost, CRC Press Boca Raton

Suzuki, T., Watanabe, Y., Ozawa, G. \& Ikeda, S. (1998) Removal of soluble organics and manganese by a hybrid MF hollow fiber membrane system, Desalination 117(1-3), 119-129.

Takizawa, S., Fu, L., Pradhan, N., Ike, T., Ohtaki, M. \& Ohgaki, S. (2001) Pretreatment processes for membrane filtration of raw water containing manganese, Water Science and Technology: Water Supply 1(5-6), 341-348.

Tansel, B., Sager, J., Rector, T., Garland, J., Strayer, R. F., Levine, L., Roberts, M., Hummerick, M. \& Bauer, J. (2006) Significance of hydrated radius and hydration shells on ionic permeability during nanofiltration in dead end and cross flow modes, Separation and Purification Technology 51(1), 40-47.

Teng, Z., Yuan Huang, J., Fujita, K. \& Takizawa, S. (2001) Manganese removal by hollow fiber micro-filter. Membrane separation for drinking water, Desalination 139(1-3), 411-418.

U.S. Environmental Protection Agency. (1991) "MINTEQA2/PRODEFA2, A Geochemical Assessment Model for Environmental Systems: Version 3.0 User Manual", USEPA, Athens, GA. 
De Munari, A. ; Schäfer, A.I. ; (2010) Impact of speciation on removal of manganese and organic matter using nanofiltration,

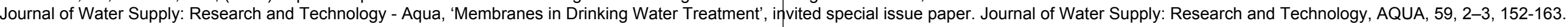
doi: 10.2166/aqua.2010.067

Van der Bruggen, B. \& Vandecasteele, C. (2003) Removal of pollutants from surface water and groundwater by nanofiltration: overview of possible applications in the drinking water industry, Environmental Pollution 122(3), 435-445.

Weber, T., Allard, T. \& Benedetti, M. F. (2006a) Iron speciation in interaction with organic matter: Modelling and experimental approach, Journal of Geochemical Exploration 88(1-3), 166-171.

Weber, T., Allard, T., Tipping, E. \& Benedetti, M. F. (2006b) Modeling iron binding to organic matter, Environ. Sci. Technol 40(24), 7488-7493.

WHO. (2004) Manganese in Drinking-water, Background document for development of WHO Guidelines for Drinking-water Quality.

Wittmann, E. \& Thorsen, T. (2004) Water treatment in: Nanofiltration principles and applications 169-240. A. I. Schäfer, A. G. Fane, T. D. Waite (Eds) Elsevier: Oxford, UK.

Worch, E. (2004) Modelling the solute transport under nonequilibrium conditions on the basis of mass transfer equations, Journal of Contaminant Hydrology 68(1-2), 97-120.

\section{List of Tables}

Table 1. Summary of manganese removal studies with MF and UF membranes

Table 2. Characteristics of TFC-SR2 and TFC-SR3 membranes. (1) Koch Membrane System Fluid Datasheets (2) $20 \mathrm{mM} \mathrm{NaCl}$, pressure: 5 bar (3) Average of all measurements performed in the study (4) Background electrolyte $1 \mathrm{mM} \mathrm{NaHCO}_{3}$ and $20 \mathrm{mM} \mathrm{NaCl}$ 
Table 1

\begin{tabular}{|c|c|c|c|c|c|}
\hline Feed Water & Source & Process & Pretreatment & Mn Removal & Reference \\
\hline \multirow[t]{3}{*}{$\mathrm{Mn}$} & \multirow[t]{3}{*}{ artificial } & \multirow[t]{3}{*}{ MF } & aeration & not effective & \multirow[t]{3}{*}{ (Abdur Rahman et al. 2000) } \\
\hline & & & $\mathrm{pH}$ level of 9.7 & $97 \%$ & \\
\hline & & & $\mathrm{H}_{2} \mathrm{O}_{2}+\mathrm{UV}$ irradiation & not effective & \\
\hline \multirow[t]{2}{*}{ Mn } & \multirow[t]{2}{*}{ artificial } & \multirow[t]{2}{*}{ MF } & $\mathrm{H}_{2} \mathrm{O}_{2}+$ UV irradiation ay $\mathrm{pH} 9.3$ & $95 \%$ after $50 \mathrm{~h}$ & \multirow[t]{2}{*}{ (Teng et al. 2001) } \\
\hline & & & Mn sand & over $95 \%$ & \\
\hline \multirow[t]{3}{*}{ Mn } & \multirow[t]{3}{*}{ natural GW } & \multirow[t]{3}{*}{ MF } & fluidised-bed with $\mathrm{Cl}_{2}$ oxidation & $90 \%$ & \multirow[t]{3}{*}{ (Takizawa et al. 2001) } \\
\hline & & & fluidised-bed with biological oxidation & $87 \%$ & \\
\hline & & & fixed-bed with biological oxidation & $100 \%$ & \\
\hline $\mathrm{Mn}$ and $\mathrm{Fe}$ & $\begin{array}{l}\text { - } \text { artificial } \\
\text { - natural GW }\end{array}$ & MF & oxidation $+\mathrm{KMnO}_{4}$ & $96 \%$ & (Ellis et al. 2000) \\
\hline \multirow[t]{4}{*}{$\mathrm{Mn}$ and $\mathrm{Fe}$} & \multirow[t]{4}{*}{ artificial } & \multirow[t]{4}{*}{$\mathrm{MF} / \mathrm{UF}$} & aeration & not effective & \multirow[t]{4}{*}{ (Jimbo \& Goto 2001) } \\
\hline & & & $\mathrm{KMnO}_{4}$ & not effective & \\
\hline & & & $\mathrm{ClO}_{2}$ & not effective & \\
\hline & & & $\mathrm{NaClO}$ & $90 \%$ & \\
\hline $\mathrm{Mn}$ & artificial & UF & Polyacrilic acid dosed to form Mn complexes & $\begin{array}{l}\text { Almost } 100 \% \text { at } \mathrm{pH} 9,5 \% \text { at } \mathrm{pH} \\
4\end{array}$ & (Han et al. 2007) \\
\hline $\mathrm{Mn}$ & artificial & UF & None & $14.7-17.4 \%$ & $\begin{array}{l}\text { (Kabsch-Korbutowicz \& } \\
\text { Winnicki 1996) }\end{array}$ \\
\hline \multirow[t]{2}{*}{ Mn and HA } & \multirow[t]{2}{*}{ river water } & \multirow[t]{2}{*}{ MF } & Biological oxidation & \multirow{2}{*}{$\begin{array}{l}90 \% \text { but bacteria not effective al } \\
\text { water temperaute }<5{ }^{\circ} \mathrm{C}\end{array}$} & \multirow[t]{2}{*}{ (Suzuki et al. 1998) } \\
\hline & & & PAC + biological oxidation & & \\
\hline $\mathrm{Mn}$ and $\mathrm{HA}$ & artificial & UF & None & $17-38 \%$ & $\begin{array}{l}\text { (Kabsch-Korbutowicz \& } \\
\text { Winnicki 1996) }\end{array}$ \\
\hline $\begin{array}{l}\text { Mn, Fe and } \\
\text { NOM }\end{array}$ & $\begin{array}{l}\text { Dam water spiked } \\
\text { with } \mathrm{MnCl}_{2} \text { and } \\
\mathrm{FeCl}_{2}\end{array}$ & UF & Chlorination $\left(3 \mathrm{mg} / \mathrm{L}\right.$ of $\left.\mathrm{Cl}_{2}\right)$ & $31 \%$ & (Choo et al. 2005) \\
\hline
\end{tabular}

Table 2

\begin{tabular}{|l|c|c|c|c|c|c|c|}
\hline & $\begin{array}{c}\text { MWCO } \\
(1)\end{array}$ & $\begin{array}{c}\text { Estimated } \\
\text { pore radius }\end{array}$ & $\begin{array}{c}\text { Retention } \\
\mathrm{MgSO}_{4}(1)\end{array}$ & $\begin{array}{c}\text { Retention } \\
\mathrm{NaCl}(2)\end{array}$ & $\begin{array}{c}\text { Average } \\
\text { Permeability (3) }\end{array}$ & $\begin{array}{c}\text { Point of zero } \\
\text { charge (4) }\end{array}$ & $\begin{array}{c}\text { Contact } \\
\text { Angle }\end{array}$ \\
\hline & $\mathrm{g} / \mathrm{mol}$ & $\mathrm{nm}$ & $\%$ & $\%$ & $\mathrm{~L}^{-1} \mathrm{~h}^{-1} \cdot \mathrm{m}^{-1} \cdot \mathrm{bar}^{-1}$ & $\mathrm{pH}$ & ${ }^{\circ}$ \\
\hline TFC-SR2 & 486 & 0.52 & 95 & 21 & 16.1 & $4.25 \pm 0.01$ & $61.5 \pm 2.5$ \\
\hline TFC-SR3 & 167 & 0.38 & 99.4 & 30 & 5.7 & $3.84 \pm 0.01$ & $48.5 \pm 1.4$ \\
\hline
\end{tabular}


De Munari, A. ; Schäfer, A.I. ; (2010) Impact of speciation on removal of manganese and organic matter using nanofiltration,

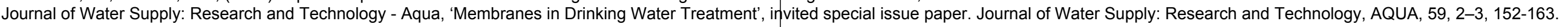
doi: 10.2166/aqua.2010.067

\section{List of Figures}

Figure 1. Stirred cells filtration system

Figure 2 (A) Manganese speciation as percentage of total manganese TOTMn, (B) manganese speciation in presence of $\mathrm{HA},(\mathrm{C})$ manganese speciation as logarithmic of the activity in absence of HA. Mn concentration: $5 \mathrm{mg} / \mathrm{L}$, HA concentration: 5 $\mathrm{mgC} / \mathrm{L}$, pressure: 5 bar, background electrolyte $1 \mathrm{mM} \mathrm{NaHCO}_{3}$ and $20 \mathrm{mM} \mathrm{NaCl}$

Figure 3. Ratio of pure water flux after ( $\mathrm{J})$ and before $\left(\mathrm{J}_{0}\right)$ experiments as a function of $\mathrm{pH}$. Mn concentration: $5 \mathrm{mg} / \mathrm{L}$, HA concentration: $5 \mathrm{mgC} / \mathrm{L}$, pressure: $5 \mathrm{bar}$, background electrolyte $1 \mathrm{mM} \mathrm{NaHCO}_{3}$ and $20 \mathrm{mM} \mathrm{NaCl}$

Figure 4. Permeability of TFC-SR2 and TFC-SR3 as a function of $\mathrm{pH}$. Mn concentration: $5 \mathrm{mg} / \mathrm{L}$, HA concentration: $5 \mathrm{mgC} / \mathrm{L}$, pressure: 5 bar, background electrolyte $1 \mathrm{mM} \mathrm{NaHCO}_{3}$ and $20 \mathrm{mM} \mathrm{NaCl}$

Figure 5. Retention of TFC-SR2 (A) and TFC-SR3 (B) as a function of $\mathrm{pH}$. Mn concentration: $5 \mathrm{mg} / \mathrm{L}$, HA concentration: $5 \mathrm{mgC} / \mathrm{L}$, pressure: 5 bar, background electrolyte $1 \mathrm{mM} \mathrm{NaHCO}_{3}$ and $20 \mathrm{mM} \mathrm{NaCl}$

Figure 6. Percentage of manganese deposit (A) and HA deposit (B) on TFC-SR2 (and TFC-SR3 as a function of $\mathrm{pH}$. Mn concentration: $5 \mathrm{mg} / \mathrm{L}$, HA concentration: 5 $\mathrm{mgC} / \mathrm{L}$, pressure: 5 bar, background electrolyte $1 \mathrm{mM} \mathrm{NaHCO}_{3}$ and $20 \mathrm{mM} \mathrm{NaCl}$

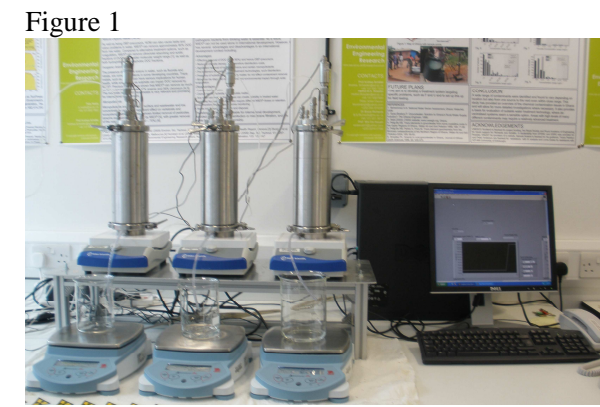


De Munari, A. ; Schäfer, A.I. ; (2010) Impact of speciation on removal of manganese and organic matter using nanofiltration,

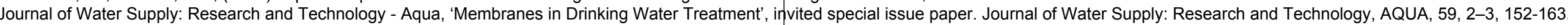
doi: 10.2166/aqua.2010.067

Figure 2

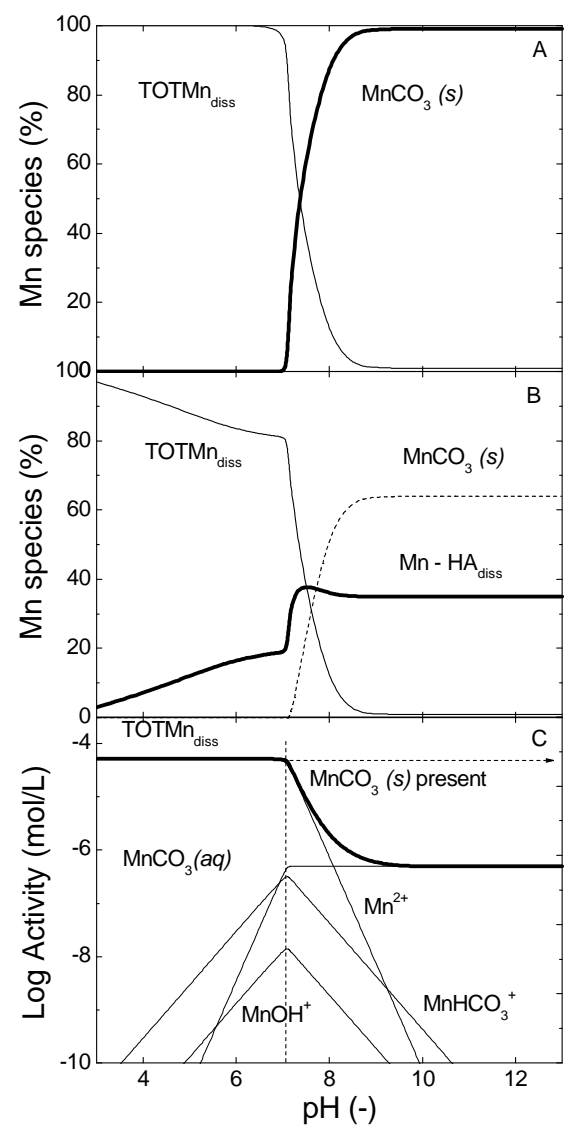

Figure 3

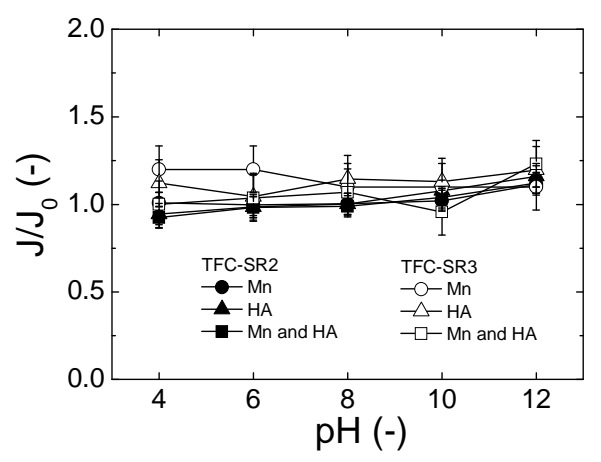


De Munari, A. ; Schäfer, A.I. ; (2010) Impact of speciation on removal of manganese and organic matter using nanofiltration,

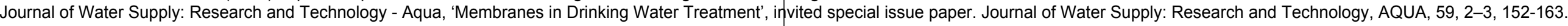
doi: 10.2166/aqua.2010.067

Figure 4

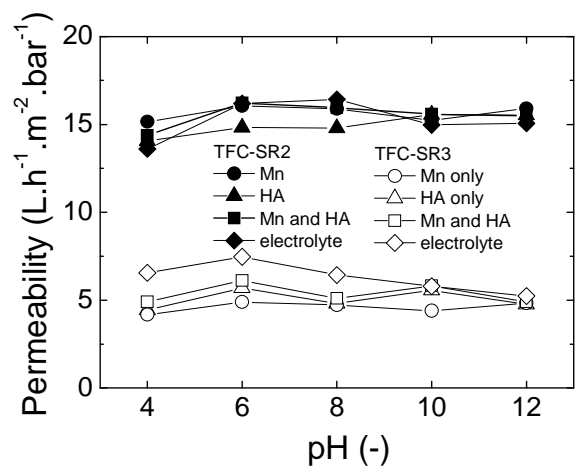

Figure 5

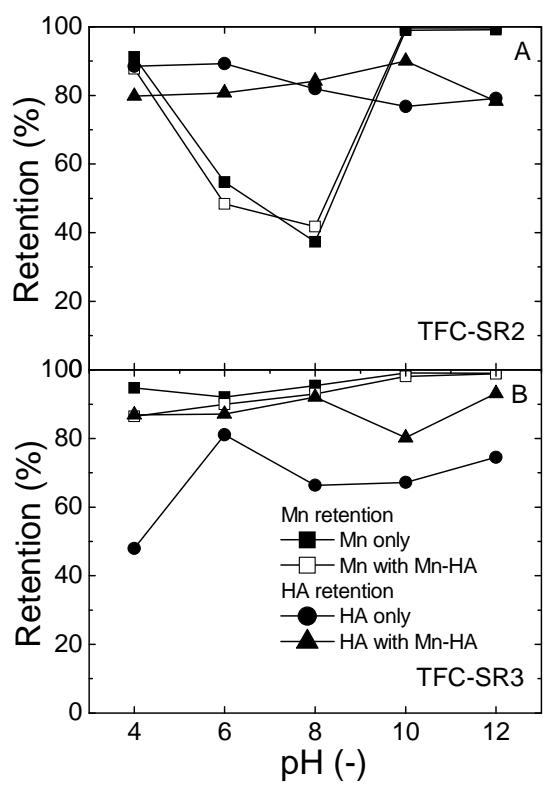


De Munari, A. ; Schäfer, A.I. ; (2010) Impact of speciation on removal of manganese and organic matter using nanofiltration,

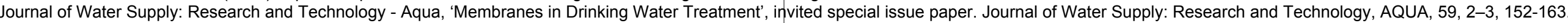
doi: 10.2166/aqua.2010.067

Figure 6

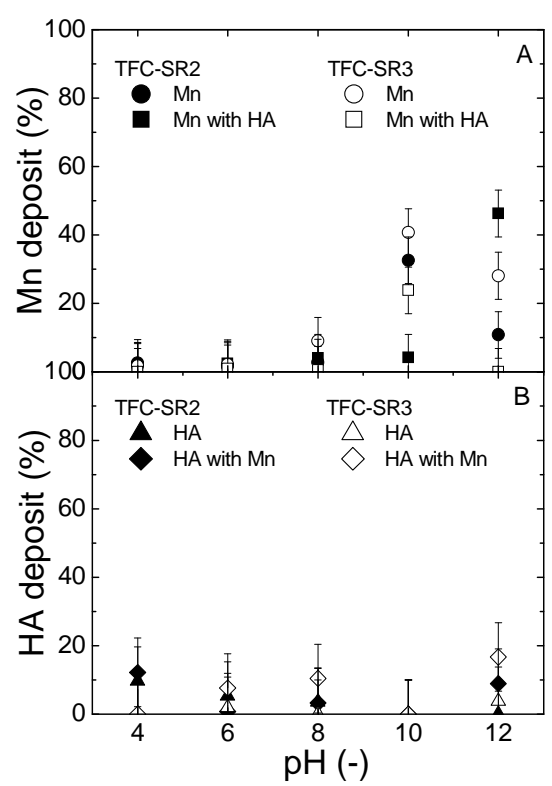

